\title{
INFLUENCE OF FERTILIZER AND WEED MANAGEMENT ON YIELD AND NUTRIENT UPTAKE IN ONION (Allium cepa L.)
}

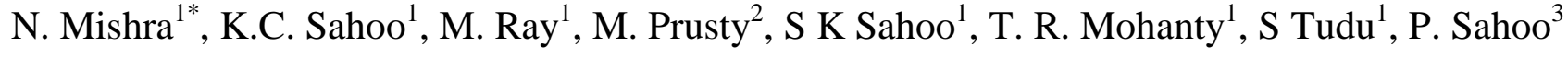 \\ ${ }^{1}$ Regional Research and Technology Transfer Station (OUAT), Keonjhar, Odisha- 758001 \\ ${ }^{2}$ Regional Research and Technology Transfer Station (OUAT), Mahisapat, Dhenkanal, Odisha-759013 \\ ${ }^{3}$ Departments of Vegetable Science, OUAT, Bhubaneswar- 751003 \\ Received - January 13, 2021; Revision - July 13, 2021; Accepted - July 20, 2021 \\ Available Online - October 20, 2021
}

DOI: http://dx.doi.org/10.18006/2021.9(Spl-3-NRMCSSA_2021).S343.S348

\section{KEYWORDS}

Onion

INM

IWM

Yield

Uptake

\begin{abstract}
A field experiment was conducted to find out appropriate nutrient and weed management practices for yield maximization and nutrient uptake of onion during rabi 2018-19 at the experimental plot of Regional Research and Technology Transfer Station, Keonjhar of Odisha. The experiment was laid out in Split plot technique with fifteen treatments viz., Main plot belongs to Nutrient management $(\mathrm{N})$ with treatments i.e. $\mathrm{N}_{1}$ - Soil test based fertilizer recommendation (STBFR), $\mathrm{N}_{2}-50 \%$ STBFR + FYM (Based on $\mathrm{N}$ requirement), $\mathrm{N}_{3}$-STBFR + Sulphur), while Subplots belongs to weed management (W) with treatments viz., $\mathrm{W}_{1^{-}}$Pendimethalin (PE) @ $0.8 \mathrm{Lha}^{-1}, \mathrm{~W}_{2^{-}}$Oxyflurofen (PE) @ $0.2 \mathrm{Lha}^{-1}, \mathrm{~W}_{3^{-}}$ Pendimethalin (PE) @ $0.8 \mathrm{Lha}^{-1}+$ one hand weeding at 25 days after transplanting(DAT), W $4^{-}$ Oxyflurofen (PE) @ $0.2 \mathrm{Lha}^{-1}+$ one hand weeding at 25 days after transplanting(DAT), $\mathrm{W}_{5^{-}}$one hand weeding at 25 days after transplanting (DAT). The highest onion bulb yield of $16.72 \mathrm{t} \mathrm{ha}^{-1}$ was obtained under the treatment applied with Pendimethalin (PE) @ $0.8 \mathrm{Lha}^{-1}$ along with one hand weeding at 25 DAT, followed by Oxyfluorfen $0.2 \mathrm{Lha}^{-1}$ pre-emergence +1 hand weeding at 25 DAT $\left(15.88 \mathrm{tha}^{-1}\right)$. The treatment combination of $\mathrm{N}_{2} \mathrm{~W}_{3}\left(96.83,16.80,57.73 \mathrm{~kg} \mathrm{ha}^{-1}\right.$ ) was recorded the highest $\mathrm{N}, \mathrm{P}$, and $\mathrm{K}$ uptake by crops respectively while $\mathrm{N}_{3} \mathrm{~W}_{3}\left(51.39 \mathrm{~kg} \mathrm{ha}^{-1}\right)$ was recorded as the highest $\mathrm{S}$ uptake by a crop over the rest of the treatments.
\end{abstract}

* Corresponding author

E-mail: nityamnjari.mishra@gmail.com (Dr. Nityamanjari Mishra)

Peer review under responsibility of Journal of Experimental Biology and Agricultural Sciences.

Production and Hosting by Horizon Publisher India [HPI] (http://www.horizonpublisherindia.in/).

All rights reserved.
All the articles published by Journal of Experimental Biology and Agricultural Sciences are licensed under a Creative Commons Attribution-NonCommercial 4.0 International License Based on a work at www.jebas.org.

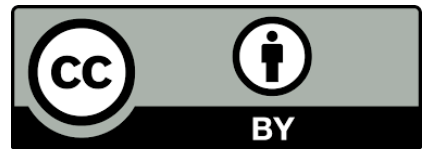




\section{Introduction}

Onion (Allium cepa $\mathrm{L}$., $2 \mathrm{n}=16$ ), belongs to the family Alliaceae, is one of the most important bulb crops used as fresh vegetable cum spice crop grown for food of therapeutic and medicinal value. Being a member of the Alliaceae family, it contains sulphur compounds like allicin and allyl propyl disulfide, etc., which give them their distinctive aroma and pungency (Meher et al., 2016).

India ranks first in area and second in production after China with an annual production of 16-17 million tones which accounts for around $20 \%$ of global production. In India, the total area producing onion during 2016-2017 was 1270.4 thousand ha with 21563.9 thousand million tonnes production and 17.0 Million tonnes per ha productivity (Horticultural Statistics at a Glance, 2017). Further, around $60 \%$ of Indian onion is predominantly cultivated during rabi season and harvested in April-May followed by $20 \%$ each during kharif season (harvested during Oct-Nov) and late kharif season (harvested in Jan-Feb) (Mishra et al., 2017). Even though India is a leading country in terms of area and production of onion but due to many factors, the productivity is very low as compared to other leading countries in the world. Weed and fertilizer management are two important aspects for the enhancement of the growth and yield of the crop.

Generally, weed infestation causes about $40-80 \%$ of bulb yield reduction (Anjali et al., 2017). Weeds compete with onion crops for light, space, soil moisture, and nutrients resulting in a considerable reduction of the bulb yield, quality, and value of the crop and also increasing production and harvesting costs of the crop (Hussain, 1983). As weeds result from the reduction of profitability of onion crops, therefore, weeds must be controlled well in time. A good weed management practice is essential for good onion production (Tripathy et al., 2013).

As, onion is a heavy feeder of mineral elements so, nutrient management practices play an important role in a good crop of onion. However, in India, intensive cropping, imbalanced fertilization, minimal usage of micronutrients, and limited application of organic manures resulting in the diminution of soil fertility (Manna, 2013). Further, the shallow root and dense population of onions make them responsive to fertilizers. So, for yield maximization, the onion crop requires higher levels of nitrogen, phosphorus, and potash fertilizer. Due to consciousness of health hazards and environmental safety, organic nutrient management has got instigation (Maji \& Das, 2008). Hence, it felt necessary to assess the different nutrient management practices along with an integrated approach for proper growth and yield. Keeping the above facts in view, the present experiment was conducted to evaluate the most viable nutrient and weed management combinations in the onion crop for the North Central Plateau Zone of Odisha.

\section{Materials and Methods}

A field experiment was conducted at the experimental plot of Regional Research and Technology Transfer Station (RRTTS), Keonjhar of Odisha during rabi 2018-19. The experimental plot is located at $21^{\circ} 55^{\prime}$ North latitude, $85^{\circ} 37^{\prime}$ 'East longitude with an altitude of $900 \mathrm{~m}$ above the MSL. The weather parameter in the experimental field was observed with total rainfall of $816.7 \mathrm{~mm}$ with 42 numbers of rainy days during the cropping period and maximum temperature $\left(36.3^{\circ} \mathrm{C}\right)$ during May 2019 , minimum temperature $(10.1$ ${ }^{0}$ C) during January 2019 (Gramin Krishi Mousam Seva report of RRTTS, Keonjhar). The texture of the soil was the loamy sand type with a $\mathrm{pH}$ of 6.4 and the average fertility status of the experimental site was available nitrogen $325 \mathrm{~kg} \mathrm{ha}^{-1}$, phosphorus $18 \mathrm{~kg} \mathrm{ha}^{-1,}$ and potassium $106 \mathrm{~kg} \mathrm{ha}^{-1}$. The experiment was laid out in the Split plot technique. There are fifteen treatments in the experiment viz., the Main plot is for Nutrient management $(\mathrm{N})$ with treatments $\mathrm{N}_{1^{-}}$soil test based fertilizer recommendation (STBFR), $\mathrm{N}_{2}-50 \%$ STBFR + FYM (Based on $\mathrm{N}$ requirement), $\mathrm{N}_{3}-\mathrm{STBFR}+$ Sulphur while subplot is for weed management $(\mathrm{W})$ and having treatments $\mathrm{W}_{1^{-}}$ Pendimethalin (PE) @ 0.8 L/ha, $\mathrm{W}_{2-}$ Oxyflurofen (PE) @ $0.2 \mathrm{Lha}^{-1}$, $\mathrm{W}_{3}$ - Pendimethalin (PE) @ $0.8 \mathrm{Lha}^{-1}+$ one hand weeding at $25 \mathrm{DAT}$, $\mathrm{W}_{4^{-}}$Oxyflurofen (PE) @ $0.2 \mathrm{Lha}^{-1}+$ one hand weeding at $25 \mathrm{DAT}$, $\mathrm{W}_{5^{-}}$Only one hand weeding at 25 days after transplanting. Seven weeks old seedlings of onion variety Nasik Red were transplanted in the field with a spacing of $15 \mathrm{~cm} \times 10 \mathrm{~cm}$. All recommended packages of practices were adapted uniformly to all the treatments for raising a good crop and the nutrient and weed management practices were done as per the treatments. Onion was harvested when the tops of the crop begin to fall and the bulbs were mature too. The data was recorded for yield $\left(\mathrm{t} \mathrm{ha}^{-1}\right)$, fresh weight of the weeds $\left(\mathrm{g} \mathrm{m}^{-2}\right)$ and were subjected to statistical analysis (Gomez \& Gomez, 1984) and treatment comparisons were made by using a t-test at a 5\% level of significance. Further, the weeds were taken randomly from the $1.0 \mathrm{~m}^{2}$ quadrate from the net plot area of each treatment, and data were collected. To determine the $\mathrm{N}, \mathrm{P}, \mathrm{K}$, and $\mathrm{S}$ content of plants and weeds, the samples were dried at $70^{\circ} \mathrm{C}$ in an oven until attained a constant weight. Then, the samples were sequentially ground by an electrical grinder for further analysis, and the required quantity of sample was weighed accurately with help of an electronic balance and used for nitrogen (Micro-Kjeldhal's method), phosphorus (Vanadomolybadate phosphoric yellow color method), potassium (flame photometric method) and sulphur (S) estimation (Jackson, 1973). Based on the nutrient content and dry matter accumulation in crops and weeds, the uptake of nitrogen, phosphorus and potassium, and sulphur by crop and weed per hectare were worked out using the formula given below and expressed in $\mathrm{kg} \mathrm{ha}^{-1}$ (Nasreen et al., 2007).

Nutrient uptake $\left(\mathrm{kg} \mathrm{ha}^{-1}\right)=$ Dry weight $\left(\mathrm{kg} \mathrm{ha}^{-1}\right) \times$ Nutrient concentration $(\%) / 100$ 


\section{Results and discussion}

\subsection{Bulb yield}

Significant variations were observed for the total bulb yield of onion with the application of a different source of fertilizers (Table $1)$. Bulb yield of onion increased $17.8 \%$ in $\mathrm{N}_{3}(\mathrm{STBFR}+\mathrm{S})$ than $\mathrm{N}_{1}$ (only application of STBFR). In conformity with these results, De-Souza et al. (2015) also reported a $16 \%$ lower in productivity of onion, when sulphur was not applied in the field. Similar findings have also been reported by Mishra et al., (2017). Integrated application of organic and inorganic produced a higher yield than the application of only STBFR. The controlled release of nutrients in the soil through mineralization of organic manures by integrated application of both organic manure and inorganic fertilizers might have facilitated better crop growth thus increasing bulb yield (Mitra et al., 2010; Thangasamy \& Lawande, 2015; Prusty et al., 2019).

A significant increase in onion bulb yield was observed with the application of both organic and inorganic fertilizer in addition to weed management practice of pre-emergence application of pendimethalin@ 0.8 1/ha along with one hand weeding at 25 days after transplanting. The treatment combination of $\mathrm{N}_{2} \mathrm{~W}_{3}$ recorded the highest bulb yield $\left(20.40 \mathrm{tha}^{-1}\right)$ followed by $\mathrm{N}_{2} \mathrm{~W}_{4}\left(18.4 \mathrm{t} \mathrm{ha}^{-1}\right)$ and $\mathrm{N}_{2} \mathrm{~W}_{5}\left(17.13 \mathrm{t} \mathrm{ha}^{-1}\right)$. However, the lowest bulb yield was recorded in treatment $\mathrm{N}_{1} \mathrm{~W}_{2}\left(11.2 \mathrm{tha}^{-1}\right)$ followed by $\mathrm{N}_{1} \mathrm{~W}_{5}$ and $\mathrm{N}_{1} \mathrm{~W}_{1}$.

The highest onion bulb yields of $16.72 \mathrm{t} \mathrm{ha}^{-1}$ were obtained under the treatment applied with Pendimethalin (PE) @ $0.81 \mathrm{ha}^{-1}$ supplement with one hand weeding at 25 DAT, followed by Oxyfluorfen 0.2 1/ha pre-emergence +1 hand weeding at 25 DAT (15. $88 \mathrm{t} \mathrm{ha}^{-1}$ ). This might be due to good weed control, which reduced the competition between crop and weed to a greater extent and thus helped in faster growth and development of onion bulb, resulting in higher yield (Patel et al., 2011).

\subsection{Fresh and dry weight of weed}

The dominant monocot weeds like Echinochloa colonum, Eleusine indica, and cynodont dactilon and dicot weeds like Trianthema ssp., Amaranthus spp., Eclipta alba were identified from the experimental plots during the investigation. However, Cyperus rotundus was the only sedge found throughout the cropping period of the onion field. After 40 days of sowing, grasses, broad-leaved weeds, and sedges accounted for about 61,35 , and $4 \%$ of the total weeds in the weedy plot of the experimental field. Similar types of weeds in the onion field were also described by Panse et al. (2014) and Anjali et al. (2017).

Different fertilizer levels had also a significant effect on the fresh and dry weight of the weeds. The fresh and dry weight of the weeds was found to be lowest $\left(49.12 \mathrm{~g} \mathrm{~m}^{-2}\right.$ and $16.77 \mathrm{~g} \mathrm{~m}^{-2}$ ) in $\mathrm{N}_{1}$ (application of
STBFR only) and highest $\left(80.10 \mathrm{~g} \mathrm{~m}^{-2}\right.$ and $\left.32.07 \mathrm{~g} \mathrm{~m}^{-2}\right)$ in $\mathrm{N}_{2}$ (application of 50\% STBFR + 50\% FYM based on N requirement). Data in Table 1 indicate that integration of both organic (FYM) and inorganic fertilizer, increased the availability of the nutrient for growth and development of the weeds resulting increased rate of the fresh and dry weight of weeds (Patel et al., 2012).

Different weed management treatments had a greater influence over the fresh and dry weight of weeds per $\mathrm{m}^{2}$. Among all the weed management practices $\mathrm{W}_{2}$ : Oxyflurofen (PE) @ 0.21 ha $^{-1}$ (78.09, $30.44 \mathrm{~g} \mathrm{~m}^{-2}$ ) recorded the highest fresh and dry weight of weed per $\mathrm{m}^{2}$ (Table 1). The maximum fresh and dry weight of weeds may be due to the continuous and increased population of weeds which might also be due to the higher amount of nutrient removal from the experimental plot. However, application of either Pendimethalin (PE) @ $0.81 \mathrm{ha}^{-1}$ or Oxyflurofen (PE) @ $0.21 \mathrm{ha}^{-1}$ along with one hand weeding at 25 days after transplanting recorded the least fresh and dry weight of the weeds. Present findings corroborated with the findings of Tripathy et al. (2008), Dudi et al. (2011), Patel et al. (2012), and Tripathy et al. (2013). However, among interaction, $\mathrm{N}_{1} \mathrm{~W}_{4}$ (application of STBFR and pre-emergence application of Oxyflurofen (PE) @ 0.21 ha $^{-1}$ along with one hand weeding at 25 days after transplanting resulted in the lowest fresh weight (38.42 $\mathrm{g}$ $\left.\mathrm{m}^{-2}\right)$ and dry weight $\left(10.46 \mathrm{~g} \mathrm{~m}^{-2}\right)$ of weeds.

\subsection{Nutrient uptake by crop and weed}

The data presented on fertilizer management on nutrient uptake crop and weed in Table 1 revealed significant variation among the treatments. Uptake of $\mathrm{N}, \mathrm{P}, \mathrm{K}$ was found to be the highest under the treatment both by crops $\left(91.35,14.59\right.$, and $\left.50.69 \mathrm{~kg} \mathrm{ha}^{-1}\right)$ and weeds $\left(4.45,1.34\right.$, and $\left.8.19 \mathrm{~kg} \mathrm{ha}^{-1}\right)$. This might be because of an increase in the rate of fertilizer, increased availability of these nutrients in soil solution, resulting in higher absorption of nutrients by the plants. However, both crop and weed uptake of $\mathrm{S}$ both by crop (44.5 kg ha ${ }^{-1}$ ) and weed (3.02 $\left.\mathrm{kg} \mathrm{ha}^{-1}\right)$ was found to be the highest under the treatment $\mathrm{N}_{3}$. The increase in nutrient uptake may also be due to the better availability of nutrients both to crops and weeds (Ananda Murthy et al., 2020).

The more nutrients are taken up by weeds affecting the availability of nutrients to the crop, which adversely affected the crop resulting in yield reduction and this was observed in the treatment $\mathrm{W}_{2}$ (Oxyflurofen (PE) @ $0.21 \mathrm{ha}^{-1}$ ). The result of nutrients removed by crops and weeds are presented in Table 1 . Results of the study revealed a significantly lower $\mathrm{N}, \mathrm{P}, \mathrm{K}$, and $\mathrm{S}$ uptake by weeds (2.57, 0.9, 5.68, and $1.5 \mathrm{~kg} \mathrm{ha}^{-1}$, respectively) and the highest uptake by crops $\left(83.52,16.01,52.93\right.$ and $44.06 \mathrm{~kg} \mathrm{ha}^{-1}$, respectively) were reported by $\mathrm{W}_{3}$ (pre-emergence application of Pendimethalin (PE) @ 0.8 1/ha + Hand weeding at 25 DAT) while the highest uptake of nitrogen, phosphorus, potassium, and sulphur by weed and lowest by crop was registered under the treatment $\mathrm{W}_{2}$. 
Table 1 Effect of Nutrient and Weed management on yield and nutrient uptake of onion

\begin{tabular}{|c|c|c|c|c|c|c|c|c|c|c|c|}
\hline \multirow{2}{*}{ Treatments } & \multirow{2}{*}{$\begin{array}{l}\text { Bulb Yield } \\
\quad\left(\mathrm{t} \mathrm{ha}^{-1}\right)\end{array}$} & \multirow{2}{*}{$\begin{array}{l}\text { Fresh weight of } \\
\text { weed }\left(\mathrm{g} \mathrm{m}^{-2}\right)\end{array}$} & \multirow{2}{*}{$\begin{array}{l}\text { Dry weight of } \\
\text { weeds }\left(\mathrm{g} \mathrm{m}^{-2}\right)\end{array}$} & \multicolumn{4}{|c|}{ Nutrient uptake by Crop $\left(\mathrm{kg} \mathrm{ha}^{-1}\right)$} & \multicolumn{4}{|c|}{ Nutrient uptake by weed $\left(\mathrm{kg} \mathrm{ha}^{-1}\right)$} \\
\hline & & & & $\mathrm{N}$ & $\mathrm{P}$ & K & S & $\mathrm{N}$ & $\mathrm{P}$ & K & S \\
\hline \multicolumn{12}{|c|}{ Nutrient Management } \\
\hline N1 & $12.46 \pm 0.95$ & $49.12 \pm 2.70$ & $16.77 \pm 0.90$ & $64.43 \pm 3.20$ & $12.45 \pm 0.75$ & $43.67 \pm 1.30$ & $27.32 \pm 1.10$ & $3.21 \pm 0.65$ & $1.09 \pm 0.14$ & $6.46 \pm 0.95$ & $1.73 \pm 0.15$ \\
\hline $\mathrm{N} 2$ & $17.25 \pm 1.05$ & $80.10 \pm 3.45$ & $32.07 \pm 1.20$ & $91.35 \pm 4.55$ & $14.59 \pm 1.60$ & $50.69 \pm 2.60$ & $36.00 \pm 1.86$ & $4.45 \pm 0.82$ & $1.34 \pm 0.26$ & $8.19 \pm 1.05$ & $2.14 \pm 0.95$ \\
\hline N3 & $14.68 \pm 0.72$ & $63.73 \pm 2.95$ & $24.37 \pm 0.75$ & $78.53 \pm 2.95$ & $16.01 \pm 0.95$ & $47.09 \pm 2.70$ & $44.50 \pm 1.92$ & $3.78 \pm 0.80$ & $1.24 \pm 0.25$ & $7.41 \pm 0.72$ & $3.02 \pm 0.82$ \\
\hline $\mathrm{CD}(0.05)$ & 0.65 & 3.74 & 1.60 & 1.31 & 0.25 & 0.95 & 2.7 & 0.37 & 0.08 & 0.5 & 0.19 \\
\hline \multicolumn{12}{|c|}{ Weed Management } \\
\hline W1 & $13.99 \pm 1.05$ & $72.86 \pm 3.92$ & $27.80 \pm 1.10$ & $75.17 \pm 4.30$ & $13.64 \pm 1.00$ & $44.66 \pm 2.70$ & $32.43 \pm 1.80$ & $4.01 \pm 0.75$ & $1.31 \pm 0.80$ & $7.91 \pm 1.10$ & $2.87 \pm 0.80$ \\
\hline W2 & $12.92 \pm 2.95$ & $78.09 \pm 4.15$ & $30.44 \pm 1.05$ & $71.77 \pm 2.05$ & $12.57 \pm 0.55$ & $40.79 \pm 2.05$ & $27.77 \pm 1.96$ & $5.32 \pm 2.00$ & $1.52 \pm 0.60$ & $8.53 \pm 2.00$ & $3.20 \pm 0.70$ \\
\hline W3 & $16.73 \pm 0.90$ & $52.72 \pm 1.25$ & $18.35 \pm 0.95$ & $83.52 \pm 4.05$ & $16.01 \pm 1.75$ & $52.93 \pm 3.10$ & $44.06 \pm 2.05$ & $2.57 \pm 0.82$ & $0.9 \pm 0.15$ & $5.68 \pm 0.90$ & $1.50 \pm 0.95$ \\
\hline W4 & $15.88 \pm 1.60$ & $54.09 \pm 1.50$ & $20.62 \pm 1.86$ & $81.63 \pm 3.00$ & $15.06 \pm 2.00$ & $50.14 \pm 3.05$ & $40.20 \pm 1.86$ & $3.47 \pm 1.15$ & $1.11 \pm 0.25$ & $6.86 \pm 0.55$ & $1.66 \pm 0.60$ \\
\hline W5 & $14.47 \pm 1.92$ & $63.83 \pm 3.66$ & $24.81 \pm 1.05$ & $78.42 \pm 4.85$ & $14.47 \pm 0.75$ & $47.22 \pm 1.70$ & $35.24 \pm 2.85$ & $3.70 \pm 1.00$ & $1.27 \pm 0.40$ & $7.79 \pm 1.00$ & $2.26 \pm 0.50$ \\
\hline $\mathrm{CD}(0.05)$ & 0.84 & 4.83 & 2.06 & 1.69 & 0.33 & 1.23 & 3.49 & 0.48 & 0.1 & 0.65 & 0.25 \\
\hline \multicolumn{12}{|c|}{ Integrated Treatments } \\
\hline N1W1 & $11.77 \pm 0.72$ & $56.5 \pm 1.25$ & $20.32 \pm 1.10$ & $63.17 \pm 4.05$ & $11.77 \pm 1.00$ & $41.50 \pm 1.30$ & $22.72 \pm 1.95$ & $3.5 \pm 0.82$ & 1.21 & $6.77 \pm 1.10$ & $2.44 \pm 0.80$ \\
\hline N1W2 & $11.20 \pm 0.90$ & $61.4 \pm 3.66$ & $22.85 \pm 1.05$ & $57.63 \pm 3.20$ & $11.20 \pm 1.60$ & $37.70 \pm 3.10$ & $17.85 \pm 0.90$ & $4.6 \pm 0.90$ & $1.41 \pm 0.80$ & $7.57 \pm 1.05$ & $2.6 \pm 0.50$ \\
\hline N1W3 & $14.03 \pm 1.60$ & $44.65 \pm 2.95$ & $12.67 \pm 2.95$ & $69.23 \pm 4.55$ & $13.77 \pm 1.75$ & $48.23 \pm 3.66$ & $36.39 \pm 1.10$ & $2.0 \pm 0.85$ & $0.78 \pm 0.15$ & $5.10 \pm 0.48$ & $0.93 \pm 0.15$ \\
\hline N1W4 & $13.40 \pm 1.00$ & $38.42 \pm 1.30$ & $10.46 \pm 0.90$ & $67.80 \pm 2.95$ & $13.10 \pm 0.95$ & $46.47 \pm 2.60$ & $32.58 \pm 1.30$ & $2.8 \pm 0.80$ & $0.86 \pm 0.10$ & $6.00 \pm 0.55$ & $1.04 \pm 0.42$ \\
\hline N1W5 & $11.90 \pm 0.75$ & $44.65 \pm 2.70$ & $17.54 \pm 0.95$ & $64.33 \pm 4.30$ & $12.43 \pm 1.35$ & $44.43 \pm 2.70$ & $27.06 \pm 1.80$ & $3.2 \pm 0.65$ & $1.18 \pm 0.60$ & $6.87 \pm 1.00$ & $1.65 \pm 0.60$ \\
\hline $\mathrm{N} 2 \mathrm{~W} 1$ & $16.17 \pm 0.95$ & $91.84 \pm 3.45$ & $35.44 \pm 1.20$ & $87.70 \pm 3.75$ & $13.73 \pm 0.80$ & $47.63 \pm 3.55$ & $32.78 \pm 2.10$ & $4.6 \pm 1.00$ & $1.42 \pm 0.50$ & $9.23 \pm 1.10$ & $2.76 \pm 0.45$ \\
\hline $\mathrm{N} 2 \mathrm{~W} 2$ & $14.17 \pm 1.92$ & $96.42 \pm 3.10$ & $38.62 \pm 1.86$ & $85.43 \pm 4.15$ & $12.23 \pm 0.55$ & $43.57 \pm 2.95$ & $26.66 \pm 1.15$ & $6.4 \pm 1.15$ & $1.65 \pm 0.75$ & $9.60 \pm 1.05$ & $2.8 \pm 0.95$ \\
\hline N2W3 & $20.40 \pm 1.05$ & $61.46 \pm 2.60$ & $26.08 \pm 0.70$ & $96.83 \pm 5.00$ & $16.80 \pm 1.88$ & $57.7 \pm 33.05$ & $44.39 \pm 1.70$ & $3.1 \pm 0.85$ & $1.06 \pm 0.25$ & $6.20 \pm 0.70$ & $1.42 \pm 0.72$ \\
\hline $\mathrm{N} 2 \mathrm{~W} 4$ & $18.40 \pm 2.95$ & $68.42 \pm 3.66$ & $28.75 \pm 0.75$ & $95.07 \pm 2.05$ & $15.57 \pm 1.20$ & $54.27 \pm 3.45$ & $41.13 \pm 2.95$ & $4.0 \pm 2.00$ & $1.24 \pm 0.25$ & $7.77 \pm 0.90$ & $1.56 \pm 0.50$ \\
\hline N2W5 & $17.13 \pm 1.60$ & $82.35 \pm 3.05$ & $31.48 \pm 2.05$ & $91.70 \pm 4.05$ & $14.60 \pm 1.92$ & $50.27 \pm 2.65$ & $35.06 \pm 2.45$ & $4.2 \pm 0.85$ & $1.34 \pm 0.40$ & $8.17 \pm 0.65$ & $2.18 \pm 0.72$ \\
\hline N3W1 & $14.03 \pm 0.85$ & $70.24 \pm 4.15$ & $27.64 \pm 1.90$ & $74.63 \pm 3.15$ & $15.43 \pm 2.00$ & $44.83 \pm 1.50$ & $41.8 \pm 2.05$ & $3.9 \pm 1.05$ & $1.30 \pm 0.45$ & $7.73 \pm 0.81$ & $3.4 \pm 0.83$ \\
\hline N3W2 & $13.40 \pm 1.10$ & $76.45 \pm 3.92$ & $29.84 \pm 1.90$ & $72.23 \pm 3.60$ & $14.27 \pm 1.05$ & $41.10 \pm 1.25$ & $38.8 \pm 1.25$ & $4.9 \pm 0.80$ & $1.51 \pm 0.35$ & $8.43 \pm 0.92$ & $4.2 \pm 0.95$ \\
\hline N3W3 & $15.77 \pm 1.00$ & $52.06 \pm 2.70$ & $18.52 \pm 0.95$ & $84.50 \pm 3.05$ & $17.47 \pm 2.00$ & $52.83 \pm 1.95$ & $51.39 \pm 3.00$ & $2.6 \pm 0.65$ & $0.86 \pm 0.14$ & $5.73 \pm 0.95$ & $2.16 \pm 0.85$ \\
\hline N3W4 & $15.83 \pm 0.90$ & $55.44 \pm 2.05$ & $20.44 \pm 1.45$ & $82.03 \pm 3.90$ & $16.50 \pm 1.70$ & $49.70 \pm 2.05$ & $46.9 \pm 2.00$ & $3.6 \pm 0.950$ & $1.24 \pm 0.30$ & $6.80 \pm 0.52$ & $2.38 \pm 0.65$ \\
\hline N3W5 & $14.37 \pm 0.90$ & $64.48 \pm 3.55$ & $25.42 \pm 2.15$ & $79.23 \pm 2.85$ & $16.37 \pm 0.75$ & $46.97 \pm 2.70$ & $43.6 \pm 1.30$ & $3.8 \pm 0.75$ & $1.29 \pm 0.30$ & $8.33 \pm 0.60$ & $2.95 \pm 0.70$ \\
\hline $\mathrm{CD}(0.05)$ & 1.43 & 8.37 & 3.57 & 2.93 & 0.57 & 2.13 & 6.04 & 0.83 & 0.17 & 1.13 & 0.42 \\
\hline
\end{tabular}


Nutrient depletion decreased with the adoption of weed contro programme might be due to lower weed population and lower fresh and dry matter production. These results are in agreement with the findings of Patel et al. (2012).

The treatment combination of $\mathrm{N}_{2} \mathrm{~W}_{3}\left(96.83,16.80,57.73 \mathrm{~kg} \mathrm{ha}^{-1}\right)$ recorded the highest $\mathrm{N}, \mathrm{P}$, and $\mathrm{K}$ uptake by crops respectively while $\mathrm{N}_{3} \mathrm{~W}_{3}\left(51.39 \mathrm{~kg} \mathrm{ha}^{-1}\right)$ was recorded the highest $\mathrm{S}$ uptake by a crop over the rest of the treatment combinations. However, the treatment combination of $\mathrm{N}_{2} \mathrm{~W}_{2}$ was recorded the highest $\mathrm{N}(6.4 \mathrm{~kg}$ $\left.\mathrm{ha}^{-1}\right), \mathrm{P}\left(1.65 \mathrm{~kg} \mathrm{ha}^{-1}\right)$, and $\mathrm{K}\left(9.60 \mathrm{~kg} \mathrm{ha}^{-1}\right)$ uptake by weeds while the treatment $\mathrm{N}_{3} \mathrm{~W}_{2}\left(4.2 \mathrm{~kg} \mathrm{ha}^{-1}\right)$ was recorded the highest $\mathrm{S}$ uptake by a crop over rest of the treatment combinations. These results were supported by the research result reported by Nasreen et al (2007), and Patel et al. (2012).

\section{Conclusions}

Application of 50\% STBFR and 50\% FYM based on $\mathrm{N}$ requirement along with weed management practice, pre-emergence application of pendimethalin @ $0.81 \mathrm{ha}^{-1}+$ Hand weeding at 25 DAT recorded highest bulb yield $\left(20.40 \mathrm{tha}^{-1}\right)$ followed by $\mathrm{N}_{2} \mathrm{~W}_{4}$ $\left(18.4 \mathrm{t} \mathrm{ha}^{-1}\right)$ and $\mathrm{N}_{2} \mathrm{~W}_{5}\left(17.13 \mathrm{t} \mathrm{ha}^{-1}\right)$ as well as highest nutrient uptake.

\section{References}

Ananda Murthy HC, Nair AK, Kalaivanan D, Anjanappa M, Shankara Hebbar S, Laxman RH (2020) Effect of NPK fertigation on post-harvest soil nutrient status, nutrient uptake and yield of hybrid ridge gourd [Luffa acutangula (L.) Roxb] Arka Vikram. International Journal of Chemical Studies 8(4): 3064-3069. DOI: https://doi.org/10.22271/chemi.2020.v8.i4ak.10117.

Anjali MG, PATIL N, Ughade J D (2017) Effect of integrated weed management on growth, yield and economic returns on onion (Allium cepa L.). The Asian Journal of Horticulture 12 (2): 193 197.

Horticultural Statistics at a Glance (2017) Govt. of India, ministry of agriculture and farmers welfare. Department of agriculture, cooperation and farmers welfare horticulture statistics division.

De Souza LFG, Filho ABC, de Tulio FA, Nowaki RHD (2015) Effect of sulphur dose on the productivity and quality of onions. Australian Journal of Crop Science 9: 728-733.

Dudi BS, Dhankar SK, Singh J (2011) Effect of weed management practices on yield and its component in onion on Hisar-2. National Symposium On Alliums: Current Scenario and Emerging Trends, $12-14^{\text {th }}$ March, 2011, Pune, pp. 254-55.
Gomez KA, Gomez AA (1984) Statistical Procedures for Agricultural Research, 2nd ed., John Wiley and Sons, Inc. UK.

Hussain F (1983) Biochemical constituent (allelopathy) a less understood ecological factor in Agro-ecosystems. Progressive Farmers 3: 33-37.

Jackson ML (1973) Soil Chemical Analysis. Prentice Hall of India, New Delhi, 4:98.

Maji S, Das BC (2008) Quality improvement of guava: an organic approach. Journal of Asian Horticulture 4: 191-95.

Manna D (2013) Growth, yield and bulb quality of onion (Allium cepa L.) in response to foliar application of boron and zinc. SAARC Journal of Agriculture 11(1): 149-153.

Meher R, Mandal J, Saha D, Mohanta S (2016) Effect of sulphur application in onion (Allium cepa L.), Journal of Crop and Weed 12(3):86-90.

Mishra N, Patro H, Ray M, Das S (2017) Effect of Sulphur Sources and levels on Growth and Yield of Onion (Allium cepa L.), Indian Agriculturist 61(1 \&2): 43-46.

Mitra S, Roy A, Saha AR, Mitra DN, Sinha MK, Mahapatra BS, Saha S (2010) Effect of integrated nutrient management on fibre yield, nutrient uptake and soil fertility in jute (Corchorus olitorius). Indian Journal of Agricultural Science 80: 801-804.

Nasreen S, Haque M M, Hossain MA, Farid ATM (2007) Nutrient uptake and yield of onion as influenced by nitrogen and sulphur fertilization Bangladesh. Journal of Agricultural Research 32(3): 413-420.

Panse R, Gupta A, Jain PK, Sasode DS, Sharma S (2014) Efficacy of different herbicides against weed flora in Onion (Allium cepa. Lindeman). Journal of Crop and Weed 10 (1): 163-166.

Patel TU, Patel CL, Patel DD, Thanki JD, Arvadia MK, Vaidya HB (2012) Performance of onion under weed and fertilizer management. Indian Journal of Weed Science 44(3): 151-158.

Patel TU, Patel CL, Patel DD, Thanki JD, Patel PS, Jat RA (2011) Effect of weed and fertilizer management on weed control and productivity of onion (Allium cepa). Indian Journal of Agronomy 56 (3): $267-272$.

Prusty M, Mishra N, Kar DS, Pal S (2019) Effect of integrated nutrient management on growth and yield of onion (Allium cepa L.) cv. Bhima Super. International Journal of Agriculture Sciences 11(4): 7910-7912. 
Thangasamy A, Lawande KE (2015) Integrated nutrients management for sustainable onion production. Indian Journal of Horticulture 72(3): 347-352.

Tripathi PC, Sankar V, Lawande KE (2008) Weed management in directly sown onion. In: ISWS Biennial Conference on Weed Management in Modern Agriculture: Emerging Challenges and
Opportunities, February 27-28, held at Bihar Veterinary College, Patna (Rajendra Agricultural University, Pusa, Bihar), Pp. 146.

Tripathy P, Sahoo BB, Patel D, Dash DK (2013) Weed management studies in onion (Allium cepa L.). Journal of Crop and Weed 9 (2): 210-12. 